\title{
Changes of Phenolic Compound in Pleurotus florida (Mont.) Singer due to Effect of Plant Growth Hormones and its Effect on Crop Growth and Yield
}

\author{
Ajay Chaurasia, S. K. Biswas, Kishan Lal, Arshad Husain* and Shivam Kumar \\ Department of Plant Pathology, C. S. Azad University of Agriculture and Technology, \\ Kanpur-208002 U.P., India \\ *Corresponding author
}

\section{A B S T R A C T}

\begin{tabular}{|l|}
\hline Ke y w o r d s \\
Agaricus, Lentinus, \\
Volvariella, \\
Pleurotus, \\
Auricularia, \\
Flammulina, \\
Tremella
\end{tabular}

The data presented in that among the two hormones, IAA and $\mathrm{GA}_{3}$ with different concentrations, the minimum 12 days require for spawn running stage in $\mathrm{T}_{5}$ treatment as spraying of $\mathrm{GA}_{3}$, @ 10ppm concentration, followed by $\mathrm{T}_{6}\left(\mathrm{GA}_{3} 15 \mathrm{ppm}\right)$ in case of control in the month of January. On the other hands, the minimum days require for pin head initiation is noted in $\mathrm{T}_{5}$ treatment $\left(\mathrm{GA}_{3}-10 \mathrm{ppm}\right)$ which is only 18 days against 27 days in case of $\mathrm{T}_{7}$ treatment, used as control. The harvested in 4 flushes and the data presented in the table 3 showed that the maximum yield was obtained in the first flush, than the second, third and fourth flushes. It is evident from the (Table-3) that maximum amount of total fresh weight of $P$. florida was obtained from $\mathrm{T}_{5}$ treatment where gibberellic acid is applied at concentration of $10 \mathrm{ppm}$, representing the values 410, 371, 308 and $235 \mathrm{gm}$ per bag at $1^{\text {st }}, 2^{\text {nd }}, 3^{\text {rd }}$ and $4^{\text {th }}$ harvesting, respectively. The highest amount of phenolic content is found in $\mathrm{T}_{6}$ treatment $\left(\mathrm{GA}_{3} 15 \mathrm{ppm}\right)$ with the value of $0.45 \mathrm{mg}$ GAE/ml of methanolic extract which is $7.17 \%$ increased over control. The second highest amount of phenolic content is found in treatment $T_{2}, T_{3}$ and $T_{5}$ treatment representing the value $0.44 \mathrm{mg} \mathrm{GAE} / \mathrm{ml}$ in all the cases showing 4.76 per cent higher than control. Similarly, the data presented in the table-7 showed that the highest amount of flavenoid content was found in $\mathrm{T}_{6}$ treatment $\left(\mathrm{GA}_{3} 15 \mathrm{ppm}\right)$ representing the value $0.128 \mathrm{mg} \mathrm{QE} / \mathrm{ml}$ of methanolic extract. Flavenoid content in $\mathrm{T}_{5}$ treatment $\left(\mathrm{GA}_{3} 15 \mathrm{ppm}\right)$ is $0.123 \mathrm{mg} \mathrm{QE} / \mathrm{ml}$ of methanolic extract which is second highest among the treatments. Increase in flavenoid content over control in treatment $\mathrm{T}_{6}$, and $\mathrm{T}_{5}$, is $15.3 \%$ and $10.8 \%$, over control. From the table, it is cleared that the $\mathrm{GA}_{3}$ is more effective than the IAA.

\section{Introduction}

Mushroom is classified as vegetable in the food world, but technically they are neither vegetable nor plant. They belong to the fungi kingdom. Peoples harvested mushroom from the wild for thousand years ago as a foods and medicines. The Greeks believed that mushroom provide strength for warriors in battle and Romans regarded them as "Food of Gods" or "Gods Flesh" (Chu et al., 2002), which were served only on festive occasion. Mushrooms are also known as "Flower of God" (Anderson et al., 1942). 
Globally, mushroom production represent only 7-8 namely Agaricus, Lentinus, Volvariella, Pleurotus, Auricularia, Flammulina and Tremella which contribute about $89 \%$ of the total world production (Chang, 2007).

Among which Pleurotus commonly known as Oyster mushroom (due to its oyster like shape) or "Dhingri" (Northern India) is the most important one which grown in a wide range of temperature (Reyes, 2003; Bayes et al., 2003).

The fungus can grow wide range of agricultural and industrial wastes which are made up by cellulose hemicelluloses and lignin. These wastes can be classified into different branches such as wood residues, waste paper, grasses, agricultural residues (including straw, stalks, and bagasse), domestic wastes (lignocellulosic garbage and sewage), and municipal solid wastes (Rodriguez et al., 2008).

The fungi need carbon and nitrogen source for structural and functional purposes in addition to trace elements, growth regulators and vitamins. Growth hormones influence the growth of the mushroom is a necessary aspect to be studied.

Adenipekun and Gbolagada, (2006) reported that gibberellic acid was found to be the best for the mycelial growth followed by indole acetic acid (IAA) while the poorest was 2,4 dichlorophenory acetic acid.

Application of gibberellic acid (GA), indole-3acetic acid (IAA) and 6-benzyl amino purine (BAP) at $1 \mathrm{ppm}, 10 \mathrm{ppm}, 100 \mathrm{ppm}$ and 200 ppm concentration in cultivated bed of Pleurotus sp. increased the number and weight of the sporophores including increased biological efficiency (Eswaran and Ramanujam, 1998). Keeping the above points on view, the study was undertaken as
"Changes of phenolic compound in Pleurotus florida (Mont.) Singer due to effect of plant growth hormones and its effect on crop growth and yield in the present investigation.

\section{Materials and Methods}

\section{Collection of culture of Pleurotus florida}

The pure culture of Pleurotus florida was obtained from Mushroom Research and Development Centre, Department of Plant Pathology, Chandra Shekhar Azad University of Agriculture and Technology, Kanpur, which was multiplied and maintained on freshly prepared Potato Dextrose Agar (PDA) medium in laboratory for further studies.

\section{Collection of material}

Wheat straw was obtained from the Student Research Farm Chandra Shekhar Azad University of Agriculture and Technology Kanpur (208002). The empty glucose bottle, polythene bags, grain of cereals (wheat) and other chemicals, bleaching powder were procured from the Mushroom Research and Development Centre, Department of Plant pathology, Chandra Shekhar Azad University of Agriculture and Technology Kanpur (208002).

\section{Cultivation technique}

The experiment was conducted at Mushroom Research and Development Centre, Department of Plant Pathology, Chandra Shekhar Azad University of Agriculture and Technology Kanpur during 2017-19. The golden colour wheat straw was collected from Student Research Farm of the university to conduct the experiment.

The straw was dipping in water for $12 \mathrm{hrs}$ using $2.5 \%$ formaldehyde for the purpose of sterilization. Spawning was done by freshly 
prepared spawn, generally 15-20 days old spawn which is considered the best for spawning. During spawning the treatment scheduled were given as follows:

\section{Treatment details}

$\mathrm{T}_{1}=$ spraying on straw with IAA @ 5 ppm

$\mathrm{T}_{2}=$ spraying on straw with IAA @ 10 ppm

$\mathrm{T}_{3}=$ spraying on straw with IAA @ 15 ppm

$\mathrm{T}_{4}=$ spraying on straw with $\mathrm{GA}_{3} @ 5$ ppm

$\mathrm{T}_{5}=$ spraying on straw with $\mathrm{GA}_{3} @ 10$ ppm

$\mathrm{T}_{6}=$ spraying on straw with $\mathrm{GA}_{3} @ 15$ ppm

$\mathrm{T}_{7}=$ Control

After spawning, the bags were then kept on iron rakes in the crop room for 10-15 days to complete the vegetative stages of mushroom. The crop room was maintained as temperature- $24{ }^{\circ} \mathrm{C}$, relative humidity-85-90\%, ventilation- 0.1 to $0.5 \%$, visible light in the range- 360 to $420 \mathrm{~nm}$

After 15 days bags are look like a covered with white mycelia mat.

The observations were recorded on the following parameters

Days taken for spawn running.

Days taken for pin head initiation.

No. of days require for harvesting.

Yield data - Number and weight of fruiting bodies per treatment.

Total phenol and flavonoid content in mushroom per treatment

\section{Harvesting yield}

The right shape for picking can be judged by the shape and size of the fruit body. The fruit bodies should be harvested before spore release. It is advisable to pick all the mushrooms at one time from a cube and the next flush will appear at one time. Harvested mushroom was weight at every time and calculated as gm / bag

Biological efficiency of substrate was calculated by using following formula-

$$
\begin{aligned}
& \text { Biological efficiency } \\
& =\frac{\text { Fresh weight of full body }}{\text { Dry weight of substrate }} \times 100
\end{aligned}
$$

Changes of phenolic compounds in mushroom due to effect of hormones

\section{Total phenolic content}

The method developed by Mau et al.,(2002) was used for extraction of phenolic compound and for determination of the total phenolic contents. The Folin-Ciocalteau procedure was employed and gallic acid was used as standard. Exactly, $20 \mu \mathrm{L}$ of various concentrations of gallic acid and samples, 400 $\mu \mathrm{L}$ of $0.5 \mathrm{~N}$ Folin-Ciocalteu reagent and 680 $\mu \mathrm{L}$ of distilled water were mixed and vortexed.

After 3 min incubation, $400 \mu \mathrm{L}$ of $\mathrm{Na} 2 \mathrm{CO} 3$ $(10 \%)$ solution was added and vortexed. Then the mixture was incubated for $2 \mathrm{~h}$ at $20{ }^{\circ} \mathrm{C}$ with interrupted shaking. Absorbance measurement was carried out at $760 \mathrm{~nm}$ at the end of the incubation period. The samples were performed in triplicates. A standard curve was prepared using gallic acid as a standard with different concentrations of gallic acid, and the results were expressed as $\mathrm{mg}$ (GAE) per g methanolic extracts (Waterhouse, 2002). Concentration of total phenolic 
compounds found in sample was determined by following formula:-

$\mathrm{A}=\frac{c \times v}{m}$

Where,

$\mathrm{A}=$ Total phenolic content

$\mathrm{C}=$ Concentration of gallic acid in $\mathrm{mg} / \mathrm{ml}$

$\mathrm{V}=$ Volume of Extract

$\mathrm{M}=$ Mass of extract (gm)

\section{Total flavonoid content}

The technique for preparation of mushroom extract is same as for total phenolic content (Mau et al.,(2002). However, total flavonoid content was measured with the aluminium chloride colorimetric assay. $1 \mathrm{ml}$ of aliquots and $1 \mathrm{ml}$ standard quercetin solution $(100,200$, $400,600,800,1000 \mu \mathrm{g} / \mathrm{ml}$ ) was positioned into test tubes and $4 \mathrm{ml}$ of distilled water and $0.3 \mathrm{ml}$ of $5 \%$ sodium nitrite solution was added into each. After 5 minutes, $0.3 \mathrm{ml}$ of 10 $\%$ aluminum chloride was added. At $6^{\text {th }}$ minute, $2 \mathrm{ml}$ of $1 \mathrm{M}$ sodium hydroxide was added. Finally, volume was making up to 10 $\mathrm{ml}$ with distilled water and mix well. Orange yellowish colour was developed. The absorbance was measured at $510 \mathrm{~nm}$ spectrophotometer using UVspectrophotometer. The blank was performed using distilled water. Quercetin was used as standard. The samples were performed in triplicates. The calibration curve was plotted using standard quercetin. The data of total flavonoids of dry mushroom were expressed as $\mathrm{mg}$ of quercetin equivalents/ $100 \mathrm{~g}$ of dry mass.

Concentration of total flavenoid compounds found in sample was determined as per following formula
$\mathrm{A}=\frac{c \times v}{m}$

Where,

$\mathrm{A}=$ Total flavenoid content

$\mathrm{C}=$ Concentration of quercetin in $\mathrm{mg} / \mathrm{ml}$

$\mathrm{V}=$ Volume of Extract

$\mathrm{M}=$ Mass of extract $(\mathrm{gm})$

\section{Results and Discussion}

Effect of different concentrations of IAA and $\mathrm{GA}_{3}$ on the spawn running, pin head formation harvesting days of Pleurotus florida.

\section{Spawn running}

Two hormones, namely, IAA and $\mathrm{GA}_{3}$ with different concentrations along with a control were evaluated to find out their effect on spawn running days of $P$. florida. The data presented in table 1shown that among the two hormones, IAA and $\mathrm{GA}_{3}$ with different concentrations, the minimum 12 days require for spawn running stage in $\mathrm{T}_{5}$ treatment as spraying of $\mathrm{GA}_{3}$, @ $10 \mathrm{ppm}$ concentration, followed by $\mathrm{T}_{6}\left(\mathrm{GA}_{3} 15 \mathrm{ppm}\right)$ and $\mathrm{T}_{4}\left(\mathrm{GA}_{3}\right.$ $5 \mathrm{ppm})$ treatments which takes 13 days for both the cases against 19 days in case of control in the month of January. From the table, it is cleared that among the two different hormones spawn run period was quicker in gibberellic acid treatments as compare to indole acetic acid. Khandakar (2004) and Pal et al., (2014) found that two to three weeks were require for spawn running. Nirdesh et al., (2019) also reported that different combinations of substrates gave variable response on spawn running, pin head formation and harvesting days of Pleurotus sajor caju. Alam et al., (2007) reported that the application of gibberellic acid showed a 
positive effect on number of effective fruiting body, stalk length, stalk width, and biological and economical yield compared with IAA and NAA. Pal et al., (2014) investigated that there was significant difference in growth of $P$. eous with respect to different growth regulators with the highest in gibberelic acid treatment.

\section{Pin head formation}

On the other hands, the minimum days require for pin head initiation is noted in $\mathrm{T}_{5}$ treatment $\left(\mathrm{GA}_{3}-10 \mathrm{ppm}\right)$ which is only 18 days against 27 days in case of $\mathrm{T}_{7}$ treatment, used as control. The treatment $\mathrm{T}_{6} \quad\left(\mathrm{GA}_{3} \quad 15 \mathrm{ppm}\right)$ require 19 days for pin head initiation, which was followed by $\mathrm{T}_{4}$ treatment $\left(\mathrm{GA}_{3} 5 \mathrm{ppm}\right)$, which takes 20 days. Dey (1996) reported that $\mathrm{GA}_{3}$ at the rate of $5-15 \mathrm{mg} / \mathrm{l}$ is very effective to form number of promodia and also to obtain a good yield. He also found that oyster mushrooms achieved maturity within two to three days after primordial initiation. Kaur and Atri (2016) found that among the different growth regulators namely IAA, IBA and $\mathrm{GA}_{3}$ the maximum yield was obtained with $\mathrm{GA}_{3}$ when sprayed at pin head formation as comparison to IBA and IAA. Pathamashini et al., (2009) found that pin head formation is closely related to temperature and humidity. Temperature below $17^{\circ} \mathrm{C}$ directly delays the pin head formation. Shah et al., (2004) found that the fruiting bodies appeared 3 -6 weeks after pinhead formation and took 27 -34 days later after inoculation of spawn.

\section{Harvesting days}

Similarly, the minimum with 24 days require for ready to harvest of the crop is found in $\mathrm{T}_{5}$ treatment followed by $\mathrm{T}_{6}$ and $\mathrm{T}_{4}$ treatment which are 25 and 26 days, respectively (Table 1). It is cleared from the table that the application of both growth hormones (IAA and $\mathrm{GA}_{3}$ ) at different concentrations is effective in Oyster mushroom cultivation but gibberellic acid is more effective than indole acetic acid. Khan et al., (2001) also reported that after spawn running to pin head formation took 7-8 days and fruiting body formed after 3-5 days, sporocarps may be harvested after 10-12 days. Quimio (1976, 1978) also reported that fruiting bodies appeared $3-4$ weeks after inoculation of spawn. Nirdesh et al., (2019) found that the 21 - 36 days was required for ready to harvest the crop in various combinations of substrates.

Effect of various concentrations of IAA and $\mathbf{G A}_{3}$ on growth characteristics and fruiting bodies of Pleurotus florida

\section{Number of fruiting}

Growth is important parameter for higher yield of any crops and mushroom is not exception from them. The data presented in the table 2 , showed that the maximum number of fruiting bodies is produced in treatment $\mathrm{T}_{5}$ $\left(\mathrm{GA}_{3} @ 10 \mathrm{ppm}\right)$ with the value 22 per bags against 13 fruiting bodies in case of control $\left(\mathrm{T}_{7}\right)$. Treatment $\mathrm{T}_{6}\left(\mathrm{GA}_{3} 15 \mathrm{ppm}\right)$ and $\mathrm{T}_{4}\left(\mathrm{GA}_{3}\right.$ $5 \mathrm{ppm})$ produced equal number of fruiting bodies (17) followed by treatment $T_{1}$ which produces 16 fruiting bodies. From the table it is also cleared that $\mathrm{GA}_{3}$ is found more effecting than IAA in respect to fruiting body formation. Alam et al., (2007) also reported that the application of gibberellic acid showed a positive effect on number of effective fruiting body, stalk length, stalk width, and biological and economical yield compared with IAA and NAA. Zerihun Tsegaye (2015) found that the number of fruiting bodies recorded is related to their mycelia colonization. Sarker and Chowdhury (2013) reported that the concentration level $10 \mathrm{ppm}$ and $20 \mathrm{ppm}$ produced the highest number of effective fruiting body. This similar finding has also been reported by Day et al., (2007). 
Table.1 Effect of different concentrations of plant growth regulators on spawn running, pin head formation and number of days require for harvesting of Pleurotus florida

\begin{tabular}{|c|c|c|c|}
\hline Treatment & $\begin{array}{c}\text { Average number of } \\
\text { days for spawn } \\
\text { running }\end{array}$ & $\begin{array}{c}\text { Average number of } \\
\text { days for pin head } \\
\text { initiation }\end{array}$ & $\begin{array}{c}\text { No. of days } \\
\text { require for } \\
\text { harvesting* }\end{array}$ \\
\hline $\mathrm{T}_{1}=\mathrm{IAA} @ 5 \mathrm{ppm}$ & 14 & 21 & 31 \\
\hline $\mathrm{T}_{2}=\mathrm{IAA} @ 10 \mathrm{ppm}$ & 15 & 25 & 29 \\
\hline $\mathrm{T}_{3}=\mathrm{IAA} @ 15 \mathrm{ppm}$ & 16 & 24 & 27 \\
\hline $\mathrm{T}_{4}=\mathrm{GA}_{3} @ 5 \mathrm{ppm}$ & 13 & 20 & 26 \\
\hline $\mathrm{T}_{5}=\mathrm{GA}_{3} @ 10 \mathrm{ppm}$ & 12 & 18 & 24 \\
\hline $\mathrm{T}_{6}=\mathrm{GA} 3$ @ $15 \mathrm{ppm}$ & 13 & 19 & 25 \\
\hline $\mathrm{T}_{7}$ Control & 19 & 27 & 34 \\
\hline $\mathrm{C} . \mathrm{D}$. & 3.857 & 4.636 & 5.021 \\
\hline $\mathrm{SE}(\mathrm{m})$ & 1.134 & 1.363 & 1.476 \\
\hline $\mathrm{SE}(\mathrm{d})$ & 1.604 & 1.927 & 2.087 \\
\hline $\mathrm{C} . \mathrm{V}$. & 11.005 & 8.760 & 7.474 \\
\hline
\end{tabular}

Table.2 Effect of different concentrations of plant growth regulators on fruiting ability and harvesting of Pleurotus florida

\begin{tabular}{|c|c|c|c|c|c|c|}
\hline \multirow[t]{2}{*}{ Treatments } & \multicolumn{4}{|c|}{$\begin{array}{c}\text { Fruiting ability of pleurotus florida at } \\
\text { different days }\end{array}$} & \multirow{2}{*}{$\begin{array}{l}\text { Total weight } \\
\text { of fruiting } \\
\text { body } \\
\text { production } \\
\text { (g) }\end{array}$} & \multirow{2}{*}{$\begin{array}{c}\text { Yield } \\
\text { increase } \\
\text { over } \\
\text { control } \\
(\%)\end{array}$} \\
\hline & $\begin{array}{l}5^{\text {th }} \\
(\mathrm{g})\end{array}$ & $\begin{array}{c}10^{\text {th }} \\
(\mathrm{g})\end{array}$ & $\begin{array}{l}15^{\text {th }} \\
(\mathrm{g})\end{array}$ & $\begin{array}{c}20^{\text {th }} \\
\text { g) }\end{array}$ & & \\
\hline $\mathrm{T}_{1=} \mathrm{IAA} @ 5 \mathrm{ppm}$ & 375 & 320 & 280 & 245 & 1220 & 37.07 \\
\hline $\mathrm{T}_{2}=\mathrm{IAA} @ 10 \mathrm{ppm}$ & 350 & 307 & 275 & 230 & 1162 & 30.56 \\
\hline $\mathrm{T}_{3=} \mathrm{IAA} @ 15 \mathrm{ppm}$ & 340 & 305 & 245 & 174 & 1064 & 19.55 \\
\hline $\mathrm{T}_{4=} \mathrm{GA}_{3} @ 5 \mathrm{ppm}$ & 388 & 340 & 298 & 240 & 1266 & 42.24 \\
\hline $\mathrm{T}_{5}=\mathrm{GA}_{3} @ 10 \mathrm{ppm}$ & 410 & 371 & 308 & 235 & 1324 & 48.76 \\
\hline $\mathrm{T}_{6=} \mathrm{GA} 3 @ 15 \mathrm{ppm}$ & 380 & 348 & 298 & 245 & 1271 & 42.80 \\
\hline $\mathrm{T}_{7=}$ Control & 285 & 239 & 190 & 176 & 890 & \\
\hline C.D. & 64.003 & 50.082 & 45.440 & 29.404 & 71.829 & \\
\hline $\mathrm{SE}(\mathrm{m})$ & 18.815 & 14.722 & 13.358 & 8.644 & 21.115 & \\
\hline $\mathrm{SE}(\mathrm{d})$ & 26.608 & 20.821 & 18.891 & 12.224 & 29.862 & \\
\hline C.V. & 7.368 & 6.534 & 4.903 & 5.253 & 2.550 & \\
\hline
\end{tabular}


Table.3 Effect of different concentrations of plant growth regulators on total flavonoid content of pleurotus florida

\begin{tabular}{|c|c|c|c|c|}
\hline Treatments & $\begin{array}{c}\text { Average } \\
\text { absorbance } \\
\text { at } 415 \mathrm{~nm}\end{array}$ & $\begin{array}{c}X=\frac{Y+0.01}{1.387} \\
(\mu \mathrm{g} / \mathrm{ml})\end{array}$ & $\begin{array}{c}\text { Total } \\
\text { flavonoid } \\
\text { (mg } \\
\text { QE/ml) }\end{array}$ & $\begin{array}{l}\text { Increase in } \\
\text { total flavonoid } \\
\text { content over } \\
\text { control }(\%)\end{array}$ \\
\hline 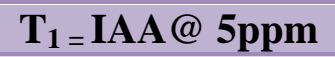 & 0.150 & 0.115 & 0.115 & 3.6 \\
\hline$T_{2}=$ IAA@ @10ppm & 0.157 & 0.120 & 0.120 & 8.1 \\
\hline$T_{3=} A @ 15 p p m$ & 0.154 & 0.118 & 0.118 & 6.3 \\
\hline $\mathbf{T}_{4=} \mathbf{G A}_{3} @ \mathbf{5 p p m}$ & 0.151 & 0.116 & 0.116 & 4.5 \\
\hline $\mathbf{T}_{5=} \mathbf{G A}_{3} @ 10 \mathrm{ppm}$ & 0.161 & 0.123 & 0.123 & 10.8 \\
\hline$T_{6=}$ GA3@15ppm & 0.168 & 0.128 & 0.128 & 15.3 \\
\hline $\mathbf{T}_{7=}$ Control & 0.145 & 0.111 & 0.111 & \\
\hline C.D. & 0.012 & & & \\
\hline SE(m) & 0.004 & & & \\
\hline SE(d) & 0.006 & & & \\
\hline C.V. & 4.466 & & & \\
\hline
\end{tabular}

Table.4 Effect of different concentrations of plant growth regulators on Total Phenol content of pleurotus florida

\begin{tabular}{|c|c|c|c|c|}
\hline Treatments & $\begin{array}{c}\text { Average } \\
\text { absorbance at } \\
750 \mathrm{~nm}\end{array}$ & $\begin{array}{c}X=\frac{Y+0.063}{0.018} \\
(\mu g / 0.1 \mathrm{ml})\end{array}$ & $\begin{array}{c}\text { Total } \\
\text { phenol (mg } \\
\text { GAE } / \mathrm{ml})\end{array}$ & $\begin{array}{l}\text { Increase in total } \\
\text { phenolic content } \\
\text { over control }(\%)\end{array}$ \\
\hline T $_{1}$ IAA 5ppm & 0.711 & 43.00 & 0.43 & 2.38 \\
\hline $\mathrm{T}_{2}$ IAA 10ppm & 0.729 & 44.00 & 0.44 & 4.76 \\
\hline T $_{3}$ IAA $15 p p m$ & 0.731 & 44.11 & 0.44 & 4.76 \\
\hline $\mathbf{T}_{4} \mathbf{G A}_{3} 5 \mathrm{ppm}$ & 0.717 & 43.33 & 0.43 & 2.38 \\
\hline $\mathrm{T}_{5} \mathbf{G A}_{3}$ 10ppm & 0.735 & 44.33 & 0.44 & 4.76 \\
\hline $\mathbf{T}_{6} \mathbf{G} \mathbf{A}_{3}$ 15ppm & 0.749 & 45.11 & 0.45 & 7.17 \\
\hline $\mathbf{T}_{7}$ Control & 0.704 & 42.61 & 0.42 & \\
\hline C.D. & 0.018 & & & \\
\hline SE(m) & 0.006 & & & \\
\hline SE(d) & 0.008 & & & \\
\hline C.V. & 1.413 & & & \\
\hline
\end{tabular}

\section{Weight of fruiting body}

The crop of Pleurotus florida was harvested in 4 flushes and the data presented in the table 3 showed that the maximum yield was obtained in the first flush, than the second, third and fourth flushes. It is evident from the (Table-3) that maximum amount of total fresh weight of
P. florida was obtained from $\mathrm{T}_{5}$ treatment where gibberellic acid is applied at concentration of $10 \mathrm{ppm}$, representing the values $410,371,308$ and $235 \mathrm{gm}$ per bag at $1^{\text {st }}, 2^{\text {nd }}, 3^{\text {rd }}$ and $4^{\text {th }}$ harvesting, respectively. The treatment $\mathrm{T}_{6}\left(\mathrm{GA}_{3} 15 \mathrm{ppm}\right)$ showing 380,348 , 298 and $245 \mathrm{gm}$ fresh weight of mushroom per bag at $1^{\text {st }}, 2^{\text {nd }}, 3^{\text {rd }}$ and $4^{\text {th }}$ harvesting stages, 
respectively which is second highest among the treatments. The treatment $\mathrm{T}_{3}$, where IAA @ 15 ppm was used representing 340, 305, 245 and $174 \mathrm{gm}$ fresh weight of mushroom per bag at $1^{\text {st }}, 2^{\text {nd }}, 3^{\text {rd }}$ and $4^{\text {th }}$ harvesting stages, respectively which is superior over control and inferior over all other treatments. From the tables, it is also cleared that the maximum amount of fresh mushroom was obtained from $1^{\text {st }}$ harvesting stages which is gradually decrease from $2^{\text {nd }}, 3^{\text {rd }}$ and $4^{\text {th }}$ harvesting stages in all the treatments. It is also cleared that both plant growth regulators IAA and $\mathrm{GA}_{3}$ is produce positive effect on Oyster mushroom cultivation. The per cent increase of yield over control was as $48.76 \%, 42.80 \%, 42.24 \%$, $37.07 \%, 30.56 \%$ and $19.55 \%$ in $\mathrm{T}_{5}, \mathrm{~T}_{6}, \mathrm{~T}_{4}, \mathrm{~T}_{1}$, $\mathrm{T}_{2}$ and $\mathrm{T}_{3}$, respectively. Nirdesh et al., (2019) found that Pleurotus sajor caju was harvested in 5 flushes, the maximum yield was obtained in the first flush, than the second and third flushes in all the treatments. They also found that the maximum yield with 1483 gm per bag was obtained from combination of substrates as $3 / 4$ wheat straw $+1 / 4$ mustard straw $+100 \mathrm{gm}$ wheat bran. Kaur and Atri, (2016) found that the maximum yield was obtained with $\mathrm{GA}_{3}$ when sprayed at pin head formation as comparison to IBA and IAA. Xavier and Kumuthakalavalli (2001) reported that application of indole acitic acid (IAA), Gibberallic acid $\left(\mathrm{GA}_{3}\right)$ and kenetin $(50 \mathrm{ppm}$ and $100 \mathrm{ppm}$ ) were increased the yield up to 46.8 and 37.8 percentage respectively over the control. Ahlawat (2003) reported that indole acetic acid, indale butyric acid, cytokinin and gibberillic effective for increasing the yield of mushrooms.

Effect of different concentrations of plant growth regulators on total phenolic and flavenoid content in mushroom

\section{Phenolic content}

The data presented in the table showed that highest amount of phenolic content is found in
$\mathrm{T}_{6}$ treatment $\left(\mathrm{GA}_{3} 15 \mathrm{ppm}\right)$ with the value of $0.45 \mathrm{mg} \mathrm{GAE} / \mathrm{ml}$ of methanolic extract which is $7.17 \%$ increased over control. The second highest amount of phenolic content is found in treatment $\mathrm{T}_{2}, \mathrm{~T}_{3}$ and $\mathrm{T}_{5}$.treatment representing the value $0.44 \mathrm{mg} \mathrm{GAE} / \mathrm{ml}$ in all the cases showing 4.76 per cent higher than control. Yim and Chye (2010) found that the phenolic contents present in the $P$. ostreatus contributed to its antioxidant activity. Park et al., (2017) reported that the IAA and $\mathrm{GA}_{3}$ at specific concentrations enhanced the growth and accumulation of total phenolic content as well as flavonoid content, including rutin and catechin.

\section{Flavonoid Compound}

Similarly, the data presented in the table - 4 showed that the highest amount of flavenoid content was found in $\mathrm{T}_{6}$ treatment $\left(\mathrm{GA}_{3}\right.$ $15 \mathrm{ppm}$ ) representing the value $0.128 \mathrm{mg}$ $\mathrm{QE} / \mathrm{ml}$ of methanolic extract. Flavenoid content in $\mathrm{T}_{5}$ treatment $\left(\mathrm{GA}_{3} 15 \mathrm{ppm}\right)$ is 0.123 $\mathrm{mg} \mathrm{QE} / \mathrm{ml}$ of methanolic extract which is second highest among the treatments. Increase in flavenoid content over control in treatment $\mathrm{T}_{6}$, and $\mathrm{T}_{5}$, is $15.3 \%$ and $10.8 \%$, over control. From the table, it is cleared that the $\mathrm{GA}_{3}$ is more effective than the IAA. Ghasmzadeh et al., (2016) reported that PGRs treatments induced the accumulation of flavonoid content over control. Kim et al., (2009) found that the variable content of flavenoid in dark grey, yellow and pink strain of Pleurotus ostreatus and according to them, dark grey strain has the highest flavenoid $(2.16 \mathrm{mg} / \mathrm{g})$ content as compared to others.

\section{References}

Adenipekun C. O. and Gbolagade J. S. (2006). Nutritional Requirements of Pleurotus florida (Mont.) Singer, A Nigerian mushroom. Pakistan Journal of Nutrition, 5: 597-600.

Anderson, E. E. and Feller, C. R. (1942). The 
food value of mushroom Agaricus campestris. American Societyof Horticulture, 41: 301-303.

Apati, G. P., Furlan, S. A. and Laurindo, J. B. (2010). Drying and Rehydration of Oyster Mushroom. Brazilian Archives of Biology and Technology. Pp. 945952.

Chang, S. T. (2007). Mushroom cultivation using the ZERI principle: potential for application. Micología Aplicada International, 19: 33-34.

Chu, K. K., Ho, S. S. and Chow, A. H. (2002). Coriolus versicolor: a medicinal mushroom with promising immunotherapeutic values. Journal of Clinical Pharmacology, 42(9):976984.

Dey R. C. (2006), Mycelial Growth and Oyster Mushroom Production with Different Hormone and Media Composition, M. S. Thesis, Department of Biotechnology, BAU, 2006.

Eswaran, A., Usharani, S. and Ramanujam, K. (1998). Mushroom Research 7: 77-78.

Ghasemzadeh A., Talei D., Jaafar H. Z. E., Juraimi A. S., Mohamed M. T. M., Puteh A. and Halim M. R. A. (2016). Plant-growth regulators alter phytochemical constituents and pharmaceutical quality in Sweet potato (Ipomoea batatas L.). BMC Complementary and Alternative Medicine. 16: 152.

Ghasemzadeh A., Talei D., Jaafar H. Z. E., Juraimi A. S., Mohamed M. T. M., Puteh A. and Halim M. R. A. (2016). Plant-growth regulators alter phytochemical constituents and pharmaceutical quality in Sweet potato (Ipomoea batatas L.). BMC Complementary and Alternative Medicine. 16: 152.

Kaur, B., and N. S. Atri (2016). "Effect of growth regulators and trace elements on the vegetative growth of pleurotus sapidus QUÃL." International Journal of Pharmacy and Pharmaceutical Sciences, 8: 283-7.

Khan, A. M., Khan, S. M. (2001), Studies on the cultivation of Oyster mushroom Pleurotus ostreatus on different substrates. Pakistan J. Phytopath., 13(2), 140-143.

Khandakar, J. (2004). Effect of media composition and growth regulators on mycelial growth and spawn production of three mushroom species. MS Thesis, Department of Biotechnology, BAU, Mymensingh.

Kim J. H., Kim S. J., Park H. R., Choi J. I., Ju Y. C., Nam K. C., and Lee S. C. (2009). The different antioxidant and anticancer activities depending on color of Oyster mushrooms, J Med Plants Res, 3: 1016-1020.

Mau and Tseng, (1998), Nonvolatile Taste Components of Three Strains of Agrocybe cylindracea, Journal of Agricultural and Food Chemistry. J. Agric. Food Chem. 466: 2071-2074.

Pal, D. P., Mishra, S. P., Shukla, C. S. and Verma, L. R. (2014). Effect of growth regulators on mycelial growth and yield of Pleurotus eous. Internat. J. agric. Sci., 10(1): 151-153.

Park, C. H., Yeo, H. J., Park, Y. J., Morgan, A. M. A., Valan Arasu, M. Al-Dhabi, N. A., Park, S. U. (2017). Influence of Indole-3-Acetic Acid and Gibberellic Acid on Phenylpropanoid Accumulation in Common Buckwheat (Fagopyrum esculentum Moench) Sprouts. Molecules, 22: 374.

Quimio, T. H. (1976), cultivation Ganoderma the pleurotus-way mushroom news letter for tropics, 6:12-30.

Rashidi, A. N. M. and Yang T. A. (2016). Nutritional and Antioxidant Values of Oyster Mushroom (P. Sajor-caju) Cultivated on Rubber Sawdust 
International. Journal on Advanced Science Engineering Information Technology. 6: 208-213.

Rodriguez G., Lama A., Rodriguez R., Jimenez A., Guillena R., FernandezBolanos J. (2008). Olive stone an attractive source of bioactive and valuable compounds. Bioresour Technol., 99: 5261-5269

Rodriguez G., Lama A., Rodriguez R., Jimenez A., Guillena R., FernandezBolanos J. (2008). Olive stone an attractive source of bioactive and valuable compounds. Bioresour Technol., 99: 5261-5269.

Sarker R. R. and. Chowdhury, A. K. M. S. H., (2013). Effect of different doses of $\mathrm{GA}_{3}$ application at primordia initiation stage on the growth and yield of Oyster mushroom. J. Bangladesh Agril. Univ. 11(1): 5-10.

Shah, Z. A, M. Ashraf and M. Ishtiaq (2004). Comparative study on cultivation and yield performance of oyster mushroom (Pleurotus ostreatus) on different substrates (wheat straw, leaves, saw dust). Pak. J. Nutrition. 3 (3):158- 160.

Signore A.D., Romeo F and Giaccio M. (1997) Content of phenolic substances in basidiomycetes. Mycological Research. 101: 552-556.

Singh, Manjit, Shwet Kamal and V.P. Sharma. (2017). Status and trends in world mushroom production-I. Mushroom Research. 26(1): 1-20.

Waterhouse, A. (2002). Determination of total phenolics. In: Current protocols in food analytical chemistry (Ed Wrolstad, R. E). John Wiley and Sons, New York, Units I1.1.1-I1.1.8.

Xavier, R. L. and kalavalli, K. R. (2001). Effect of phytohormones on the yield of gray oyster mushroom Pleurotus sajor-caju. Journal of Ecobiology. 13(4): 305-307.

\section{How to cite this article:}

Ajay Chaurasia, S. K. Biswas, Kishan Lal, Arshad Husain and Shivam Kumar. 2019. Changes of Phenolic Compound in Pleurotus florida (Mont.) Singer due to Effect of Plant Growth Hormones and its Effect on Crop Growth and Yield. Int.J.Curr.Microbiol.App.Sci. 8(12): 10261035. doi: https://doi.org/10.20546/ijcmas.2019.812.131 